\title{
USING GEOPHYSICS TO MAP BEDROCK FAULTS, DIKES, AND SURFICIAL GEOLOGY IN RELATION TO KARST FEATURES IN THE BRIERY BRANCH QUADRANGLE, ROCKINGHAM COUNTY, VIRGINIA
}

\author{
Brent B. Waters \\ Golder Associates, Inc., 2108 W Laburnum Ave., Suite 200, Richmond, VA 23227, bwaters@golder.com
}

\section{Daniel H. Doctor}

U.S. Geological Survey Eastern Geology and Paleoclimate Science Center, 12201 Sunrise Valley Drive, MS 926A, Reston,VA20192,dhdoctor@usgs.gov

\section{Joel P. Maynard}

Virginia Department of Environmental Quality, Groundwater Characterization Program, P.O. Box 3000, HarrisonburgVA22801, joel.maynard@deq.virginia.gov

\begin{abstract}
Several faults have been identified in the Cambrian and Ordovician carbonate strata in western Rockingham County, Virginia. These faults were recognized by mapping offsets between stratigraphic units in the hanging wall of the North Mountain fault system. Portions of these faults are associated with karst features, but are covered by alluvium and thick soil development in the floodplains of Dry River and Briery Branch; therefore, the position of the faults could not be located with accuracy through surface mapping alone. In an earlier study, ground penetrating radar (GPR) and audio-magnetotellurics (AMT) geophysical methods were used to locate the expression of these faults at depths greater than $\sim 5 \mathrm{~m}$. Here, we employ electrical resistivity imaging (ERI), and borehole video to examine the influence the faulting may have on near-surface karst expression. These geophysical datasets also help in the identification of igneous dikes and karst features present in the subsurface, and shed light on how these structures may affect the local groundwater flow regime and karst development.
\end{abstract}

The ERI surveys were useful in identifying the precise position of inferred bedrock faults, as well as karst features in the shallow subsurface. On the ERI profiles, the faults inferred through geologic mapping appear as sub-vertical low resistivity zones, indicating increased fracture porosity and weathering along the fault surface. Enhanced fracturing in these zones was also observed in adjacent borehole video logs. Diabase dikes appear as sub-vertical high resistivity features, and were verified at the surface through outcrop observation. Sinkholes and other karst features were also identified in the ERI profiles, generally expressed as low-resistivity anomalies. A pseudo-3D ERI survey was completed over a closed depression in highly weathered alluvium overlying limestone bedrock that clearly images the outline of the depression in the subsurface, as well as a possible water or mud-filled solutional conduit. The surface expression of the depression was approximately $165 \mathrm{ft}(50 \mathrm{~m})$ in diameter, while the low-resistivity anomaly was 15 to $50 \mathrm{ft}$ ( 5 to $15 \mathrm{~m}$ ) wide and appeared at depth of 15 to $80 \mathrm{ft}$ (5 to $25 \mathrm{~m}$ ).

\section{Introduction}

In support of detailed geologic mapping, several geophysical surveys were completed west of Harrisonburg in Rockingham County, Virginia to confirm the presence and more accurately delineate the subsurface location of faults in the northeast corner of the Briery Branch 7.5-minute (1:24,000 scale) quadrangle. These faults were recognized by mapping offsets between stratigraphic units in Cambrian and Ordovician carbonate strata in the hanging wall of the North Mountain fault system. Portions of these faults are associated with karst features, but are covered by alluvium and thick soil development in the floodplains of Dry River and Briery Branch. Due to the alluvial cover, the position of the faults could not be located with accuracy. Several geophysical techniques were used to map bedrock geologic structures including faults, fracture zones, and diabase dikes, to estimate the thickness of alluvium and deeply weathered bedrock, 
and to shed light on how these structures may affect the local groundwater flow regime and karst development.

Earlier geophysical investigations employed ground penetrating radar (GPR) and audio-magnetotellurics (AMT) as a means of investigating the depth of the alluvial cover atop the bedrock and for potentially illustrating the location of major faults at depth (Pierce and Doctor, 2011; Doctor et al., 2014). GPR that was collected with a $25 \mathrm{MHz}$ antenna was useful in mapping the thickness of the alluvial deposits to a depth of approximately $80 \mathrm{ft}(25 \mathrm{~m})$, and could identify areas of possible subsidence of layered alluvium into underlying voids (Pierce and Doctor, 2011; Doctor et al., 2014). The AMT method was capable of imaging broad resistivity contrasts along thrust faults at depths of up to $1650 \mathrm{ft}$ (500 m) (Pierce and Doctor, 2011; Doctor et al., 2014).

In the present study, electrical resistivity imaging (ERI) was used in order to provide additional detail in the near- surface. The high resolution ERI surveys successfully revealed evidence of subsurface geologic features due to the high electrical resistivity contrast between unfractured carbonate bedrock and the low resistivity of clay-infilled bedrock fracture zones and solutional features. The very high resistivity of basalt allowed for the additional imaging of an igneous dike.

\section{Methods}

Four ERI lines were completed on two farm properties along State Route 33 near the western limits of the Shenandoah Valley and north of Dry River (Figure 1). The geophysical lines ranged from 790 to $1800 \mathrm{ft}$ (240 to $550 \mathrm{~m}$ ) in length and had an estimated depth of investigation of 160 to $360 \mathrm{ft}$ (50 to $100 \mathrm{~m}$ ). The geology of the study area is shown in Figure 1. The ERI surveys were conducted above faulted and folded Cambrian and Ordovician carbonate rocks east of Cooper Mountain. A pseudo 3-dimensional ERI survey composed of 6 parallel profiles was also completed over a covered

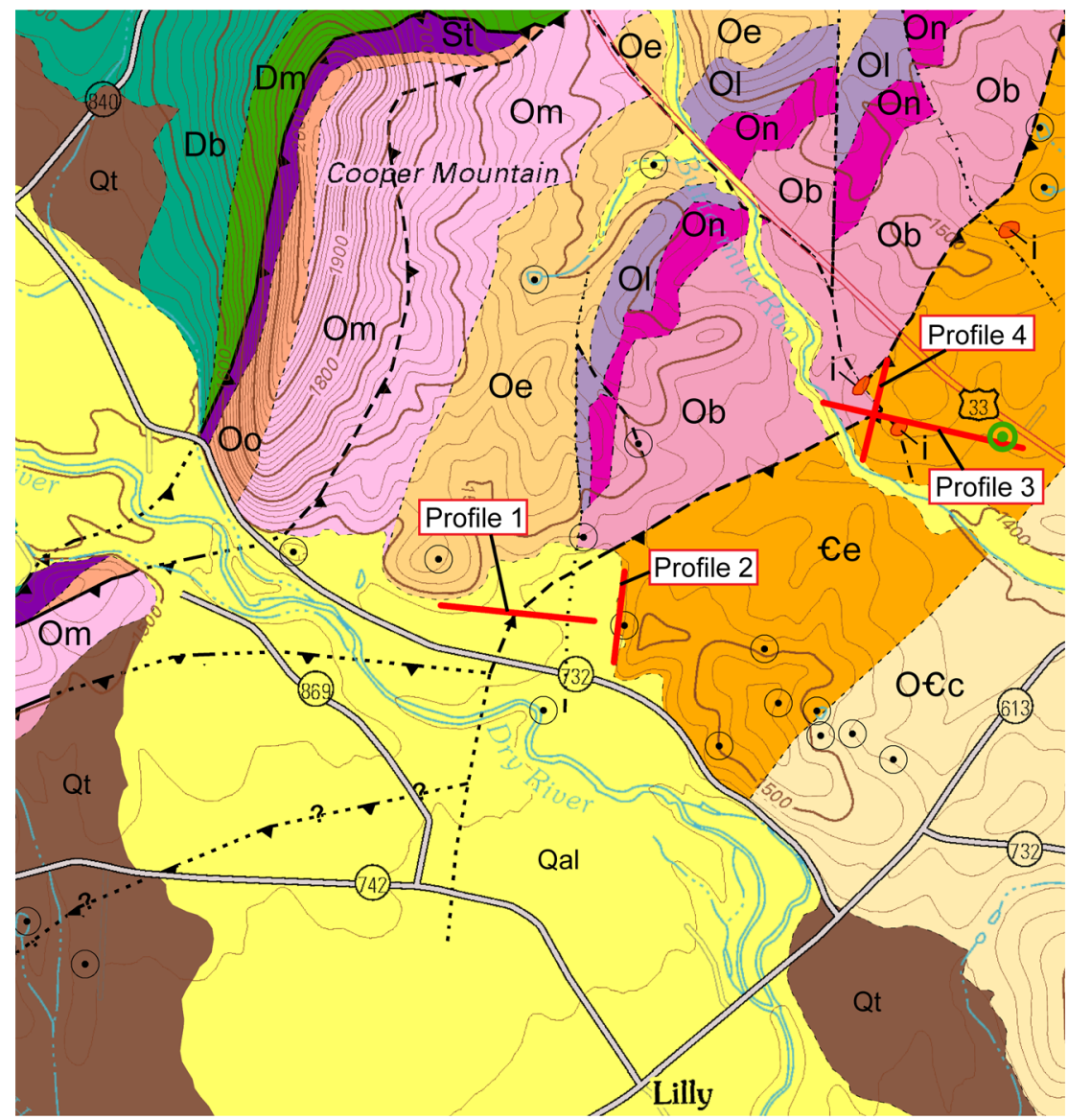

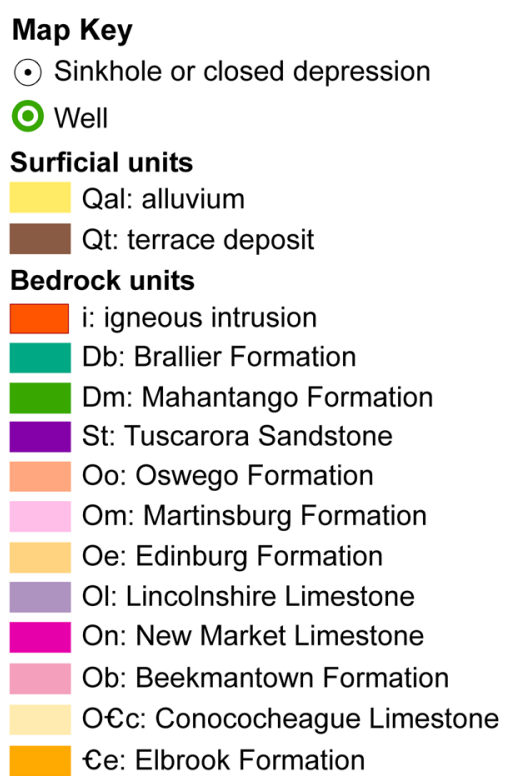

\section{Faults}

- - - approximate fault

$\longrightarrow$ thrust fault

$\cdots \nabla$ thrust fault, concealed

$--\nabla$ thrust fault, approximate

Electrical resistivity profile lines

0

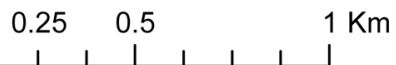

Figure 1. Draft geologic map of the study area located near Lilly, Virginia within the Briery Branch 7.5 minute quadrangle (unpublished mapping by D.H. Doctor). Electrical resistivity profile lines are shown in red. 
sinkhole located in the alluvial deposits of Briery Branch (not shown on Figure 1).

\section{Electrical Resistivity Imaging Results}

The interpretative results of the 2-D ERI profiles 1-4 are illustrated in Figures 2 and 3. All figures have the same electrical resistivity scale for ease of comparison.

ERI Profile 1 (Figure 2) was completed with 70 electrodes at a $20 \mathrm{ft}(6 \mathrm{~m})$ spacing for a total length of $1360 \mathrm{ft}(414 \mathrm{~m})$ and a theoretical depth of investigation of $270 \mathrm{ft}(83 \mathrm{~m})$. Three resistivity layers are illustrated in the ERI profile. The first layer is approximately 10 to $25 \mathrm{ft}$ thick (2 to $7.5 \mathrm{~m}$ ) and has moderately high resistivity values that range from 240 to 1500 ohmmeters (yellow to orange). This layer is interpreted as more resistive sandy alluvial deposits which are mapped beneath the entire length of ERI Line 1 terminating and possibly thinning to the west towards the beginning of the line. The second layer has a lower resistivity ( $<240$ ohm-meters) and shows up as blue on the ERI profiles. This layer extends to a depth of approximately 50 to $70 \mathrm{ft}(15$ to $21 \mathrm{~m})$ below ground surface and is interpreted to represent a combination of clayey soil and highly weathered limestone bedrock. The increased clay content, water-saturation, and fracture porosity results in the lower modeled resistivity values. The third and deepest layer is high resistivity ranging from 240 to over 4000 ohm-meters. Higher resistivity values represent competent, unweathered bedrock with a low saturated fracture porosity. Low resistivity zones detected below the suspected bedrock interface likely represent zones of increased fracture concentrations (e.g., saturated bedrock fracture zones), or soil-clay-water infilled solution voids within the carbonate bedrock. Such zones would have higher saturated fracture porosity and possibly clay content and are therefore more electrically conductive and would have a lower resistivity than the surrounding less fractured, drier bedrock. Air-filled voids would also be highly resistive and may have little contrast from the unfractured bedrock.

Two sub-vertical low resistivity zones can be observed in ERI Profile 1; both appear to be steeply dipping to the southeast and appear to project to the surface in the vicinity of electrodes \#35 and \#53. These features may represent underlying zones of increased brittle fracturing and karst weathering in the underlying bedrock. These
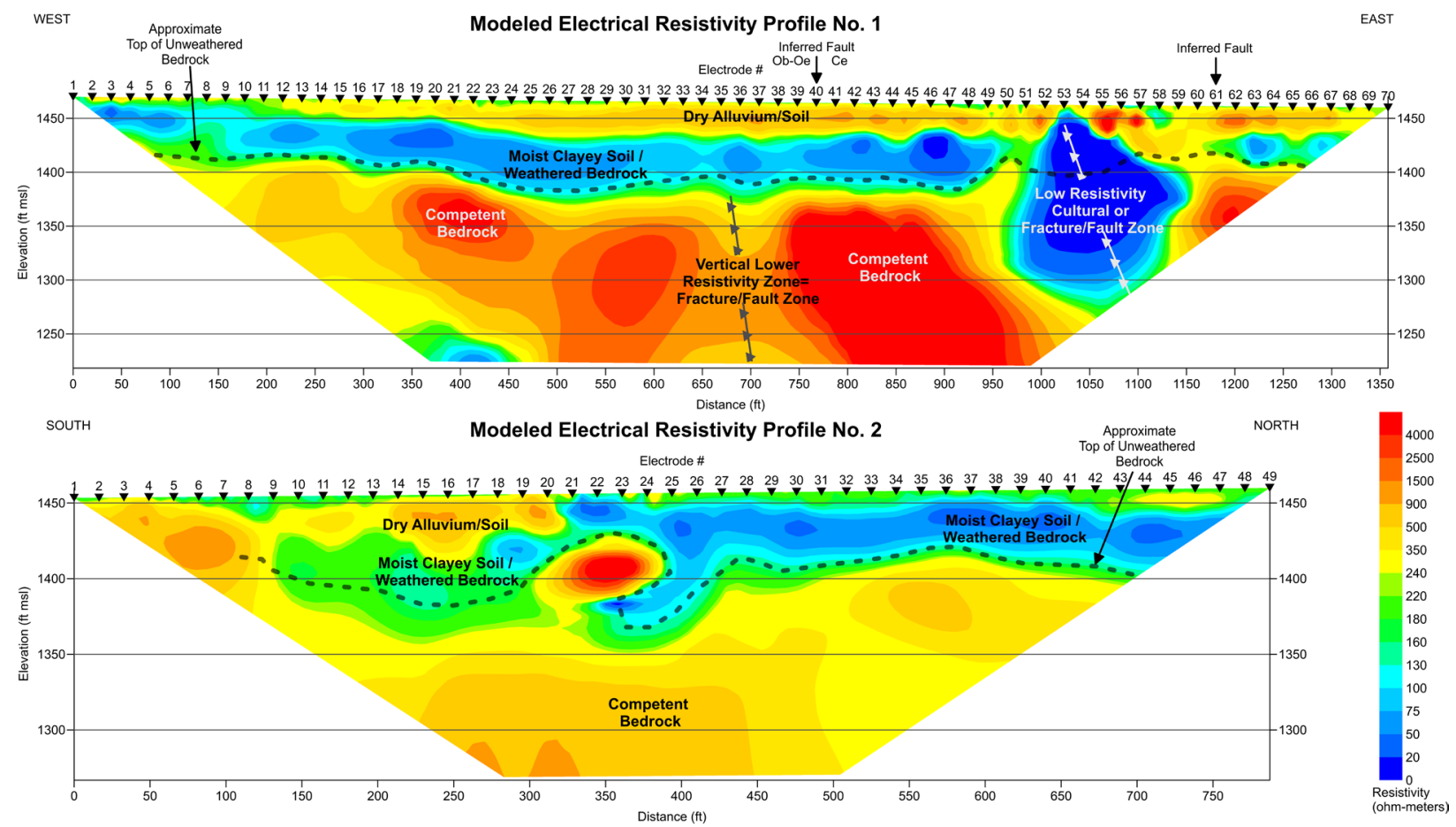

Figure 2. ERI Profile 1 (upper panel) and Profile 2 (lower panel). Note the presence of lower resistivity fracture/fault zones in the Profile 1, which correspond to inferred fault locations beneath the alluvium of the floodplain of Dry River (Figure 1). In Profile 2, a sinkhole is located at the surface near electrode 21 (1 ft=0.3048 m). 


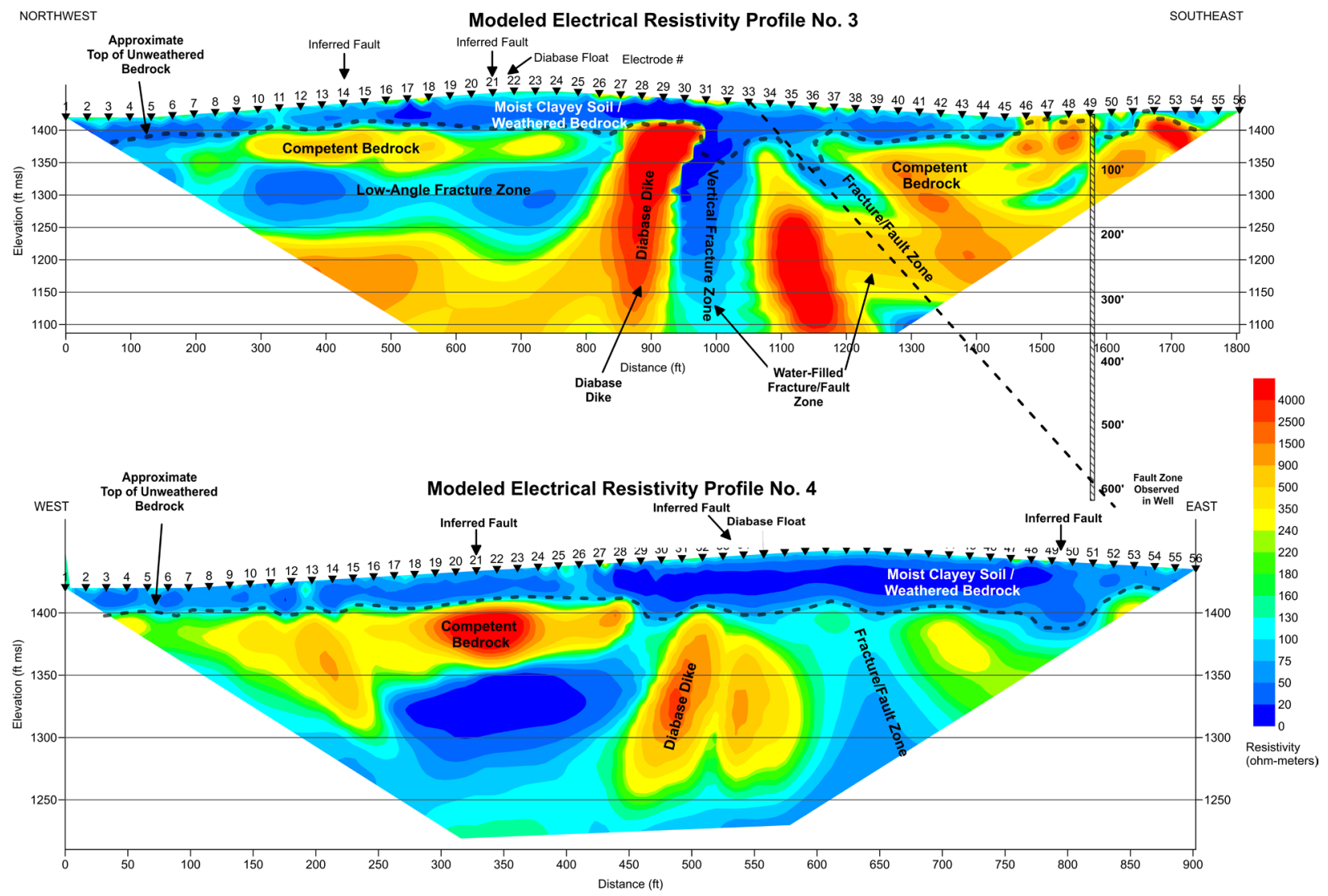

Figure 3. Electrical resistivity Profile 3 (upper panel) and Profile 4 (lower panel). Low resistivity zones are interpreted as water-filled fracture zones possibly associated with faulting, and contact metamorphism. Vertical high resistivity zones coincide with mapped diabase dikes. A fault zone observed in Simmons Well shown in Figure 1 appears to correspond with a southeastdipping low resistivity fracture zone in Profile 3. $1 \mathrm{ft}=0.3048 \mathrm{~m}$.

features are near and possibly coincidental with the two mapped faults shown in Figure 2.

While in the field, we were informed by the landowner that an old metallic shed and other trash partially fill a sinkhole that had formed in the zone of extreme low resistivity near the east end of Profile 1 . Therefore, this is a zone of potential cultural interference that explains the unusually large zone of low resistivity.

ERI Profile 2 (Figure 2) was completed with 49 electrodes at a $16 \mathrm{ft}(5 \mathrm{~m})$ spacing for a total length of 790 feet $(240 \mathrm{~m})$ and a theoretical depth of investigation of 160 feet $(50 \mathrm{~m})$. A similar three resistivity layer model is observed in this profile. The shallow high resistivity (alluvium) layer occurs beneath the southern half of the line and thins or is absent to the north away from Dry River. The second layer (clayey soil and highly weathered limestone bedrock) extends to a depth of approximately 40 to $70 \mathrm{ft}$ (12 to $21 \mathrm{~m}$ ). The underlying bedrock appears competent with no identifiable low resistivity zones. An open-throat sinkhole was observed at the surface adjacent to electrode \#22, and a possible bedrock pinnacle may occur just beneath it in the vicinity of electrodes 20-24, with a sediment-filled conduit extending below the pinnacle to a depth of nearly $100 \mathrm{ft}$ (30 m).

ERI Profile 3 (Figure 3) was completed with 56 electrodes at a $33 \mathrm{ft}(10 \mathrm{~m})$ spacing for a total length of $1800 \mathrm{ft}$ $(550 \mathrm{~m})$ and a theoretical depth of investigation of $360 \mathrm{ft}$ $(110 \mathrm{~m}$ ). ERI Profile 4 (Figure 3) was completed with 56 electrodes at $16 \mathrm{ft}(5 \mathrm{~m})$ spacing for a total length of $900 \mathrm{ft}(275 \mathrm{~m})$ and a theoretical depth of investigation of $180 \mathrm{ft}(55 \mathrm{~m})$. ERI Profiles 3 and 4 can be described using a 2 layer resistivity model since the resistive surficial alluvium layer is missing. The profiles therefore have a surficial low resistivity layer (shown in blue) representing clayey soil and highly weathered limestone bedrock overlying a higher resistivity layer representing 
competent bedrock. Low resistivity zones detected below the suspected bedrock interface likely represent fracture zones or karst voids possibly related to inferred fault locations. Sub-horizontal low resistivity zones may be stratigraphically controlled or may represent lowangle thrust zones. Sub-vertical low resistivity zones may represent steeply-dipping fracture or fault zones, such as high angle transverse faults, or may be related to increased fracture permeability found in the contact zone around a vertical diabase dike (Figure 3). Steeplydipping high resistivity zones observed in the profiles are interpreted to represent an igneous dike, as float of basalt was observed at the surface (Doctor et al., 2014).

\section{Pseudo 3-D ERI Profiles of a Sinkhole}

A pseudo 3-Dimensional electrical resistivity imaging survey was completed over a closed circular depression with internal drainage believed to represent a coversubsidence sinkhole. The underlying karst feature or sinkhole is covered by unconsolidated alluvial deposits that are mapped surrounding the Briery Branch alluvial fan. The alluvium is between 50 and $80 \mathrm{ft}$ (15 to $24 \mathrm{~m}$ ) thick and composed of weathered sand and gravel deposits. The resultant subsidence sinkhole forms a broad, shallow circular depression. Six ERI profiles were completed across the sinkhole in a northwest to southeast orientation as shown in Figure 4. Each ERI line was deployed with 28 electrodes with an electrode spacing of $16 \mathrm{ft}(5 \mathrm{~m})$ and a line spacing of $33 \mathrm{ft}$ $(10 \mathrm{~m})$. The depth of investigation for the survey was approximately $100 \mathrm{ft}(30 \mathrm{~m})$. The ERI data was analyzed as 2-D profiles and merged into a pseudo 3-D matrix and analyzed as a 3-D ERI survey. The interpretative results of the pseudo 3-D survey is shown in Figure 4.

The sand and gravel alluvium and underlying bedrock are imaged as moderately high resistivity layers. A thin circular deposit of low resistivity material occupies the center of the depression, likely reflecting the accumulation of fine silt, organic-rich soil and high soil moisture in the central part of the sinkhole. This low resistivity layer thickens to the northeast side of the circular depression where a deep, vertical low resistivity zone is imaged. This feature is believed to be the outlet pipe for the sinkhole representing a solution-widened, sediment and clay-infilled cavity if it is in the bedrock, or possibly a soil pipe if it is in unconsolidated alluvium. Piping and raveling of alluvial sediment into the underlying karst voids likely formed this soil-covered sinkhole. Note that the outlet pipe of the sinkhole is not situated in the center of the depression.
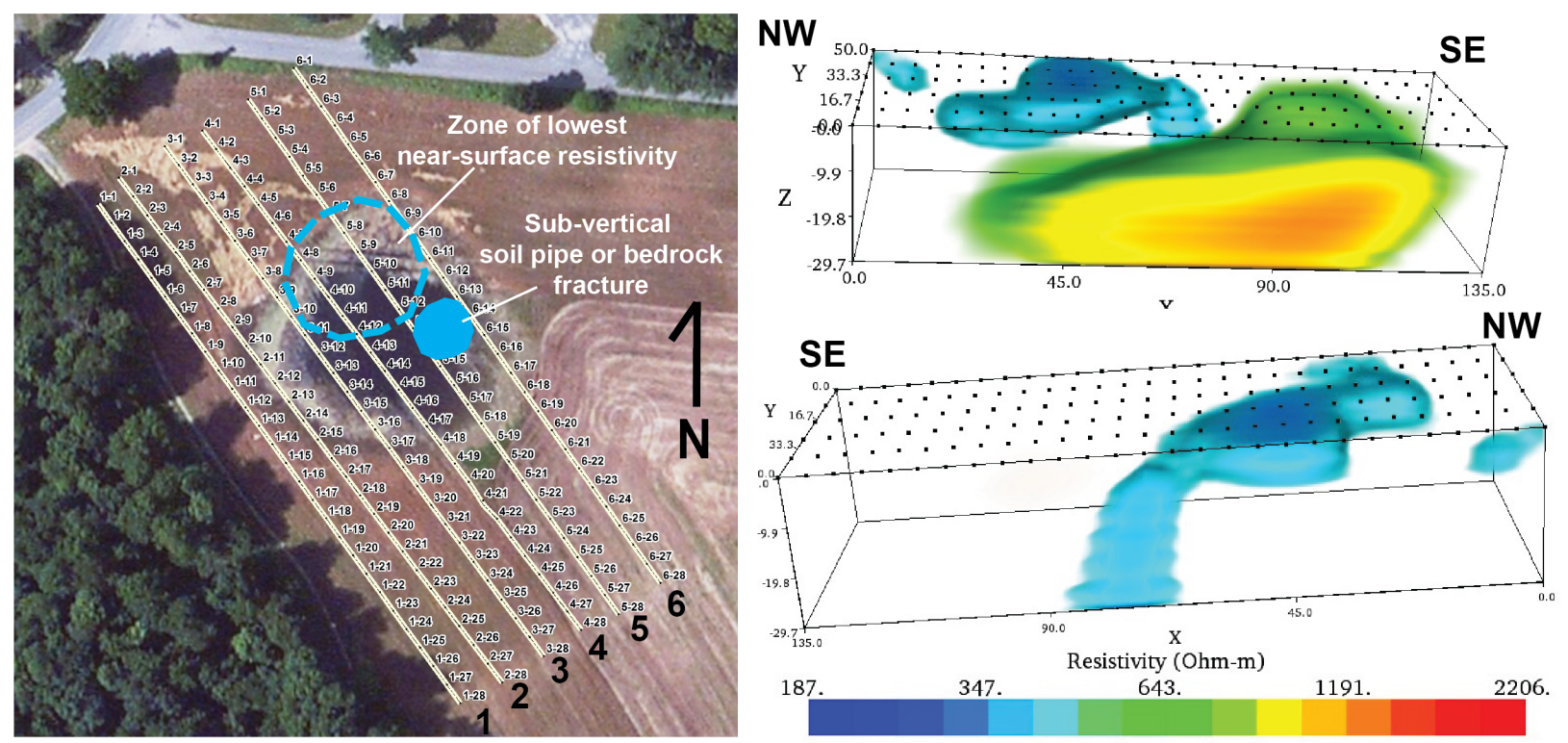

Figure 4. Location map and pseudo 3-D ERI results of a geophysical survey completed over an ephemerally ponded circular depression interpreted as a cover-subsidence sinkhole. The sinkhole is situated within alluvial fan deposits in the floodplain of Briery Branch, and is located at the intersection of State Route 731 and 750, approximately 5 miles southwest of Dry River where the ERI survey locations shown in Figure 1 were completed. Moderate and high resistivity values are not shown in the pseudo-3D ERI profiles. 


\section{Conclusions}

This study demonstrated that the use of high resolution electrical resistivity imaging can be useful for confirming the presence and refining the location of geologic features and structures where overburden deposits may obscure such details. In this instance, ERI was used to help map faults, diabase dikes, alluvial deposits, and karst features in folded and faulted carbonate bedrock in the western Shenandoah region of Virginia. ERI successfully revealed evidence of subsurface geologic features due to the high contrast between the high electrical resistivity of unfractured carbonate bedrock and the low resistivity of clay-infilled bedrock fracture zones and solutional features. The very high resistivity of basalt allowed for the additional imaging of an igneous dike. ERI surveys were equally successful in detecting areas of carbonate bedrock covered with an alluvium, and where only weathered residuum covered the bedrock. Solutional karst development along the faults is evidenced by low resistivity values extending to depths greater than 100 feet in the fault zones. This study also demonstrates the utility of using ERI surveys for detecting karst development along zones of deformation in folded and faulted carbonate bedrock.

\section{References}

Doctor DH, Orndorff W, Maynard J, Heller MJ, Casile GC. 2014. Karst geomorphology and hydrology of the Shenandoah Valley near Harrisonburg, Virginia. In: Bailey CM, Coiner LV, editors. Elevating Geoscience in the Southeastern United States: New Ideas about Old Terranes_-Field Guides for the GSA Southeastern Section Meeting, Blacksburg, Virginia, Geological Society of America Field Guide 35, p. 161-213. https:// doi.org/10.1130/2014.0035(06).

Pierce HA, Doctor DH. 2011. Multi-resolution geophysical investigations and geologic mapping of a mantled karst aquifer, Briery Branch quadrangle, Virginia, USA. Geological Society of America Annual Meeting (October 9-12, 2011), Minneapolis, Minnesota, Abstracts with Programs, 43(5), p. 145. 